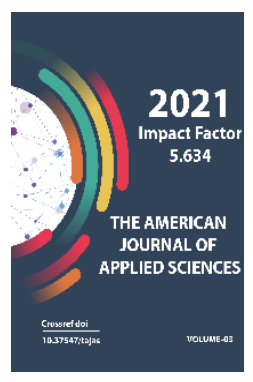

\title{
Value Of Local Resources In Increase Of Potential Of Small- Scale Business And Business
}

\author{
Nilufar Gulomjonovna Mahmudova \\ Doctoral Student Of The Speciality Of "Management", Namangan Engineering-Technological \\ Institute, Uzbekistan
}

\footnotetext{
Journal Website: http://usajournalshub.c om/index,php/tajas

Copyright: Original content from this work may be used under the terms of the creative commons attributes 4.0 licence.
}

\section{ABSTRACT}

Small-scale business and business has great value in economic potential of each state. Uses of local resources in activity of small-scale business and business provides their efficiency. Possibility of manufacture of the competitive goods is as a result provided. In article on the basis of theoretical and analytical materials the basic directions of increase of efficiency of small-scale business and business with use of local resources are defined.

\section{KEYWORDS}

Digital economy, small-scale business, business, local resources, competitiveness, efficiency.

\section{INTRODUCTION}

Today, in order to ensure the development of the countries of the world, it is necessary, first of all, to increase the middle class and entrepreneurial activity, which is the basis for its formation. According to estimates by the U.S. financial corporation Goldman Sachs, by
2050, 40 percent of world GDP will be formed by the middle class engaged in entrepreneurial activities. Historically, the figure was 23 percent in 1960 and 30 percent in 2007. 
At present, the middle class in Western countries makes up 50-70 percent of the population and is mainly engaged in entrepreneurial activities. At the current level of socio-economic development of Uzbekistan, the entrepreneurial activity of the middle class is developing, and in the future, the knowledge will grow even faster. Entrepreneurs are becoming the backbone and backbone of society and the economy. The experience of American, Asian and European countries shows that the basis of any country's development is small business and entrepreneurship.

The pandemic situation in the world requires the use of effective tools to manage the economy in various sectors and industries. In other words, the shadow of this crisis is increasingly covering developed and developing countries. As a result, there is a decline in production, rising unemployment and deteriorating living standards in these countries. As the economies of countries become more deeply integrated into the world economic and economic-financial system, the consequences of the crisis, of course, will affect all countries.

In his Address to the Oliy Majlis of the Republic of Uzbekistan, President Mirziyoyev paid special attention to this issue, noting that despite the problems and difficulties, in 2020 the country's economy was not only stable, but also consistent growth. In accordance with the programs for 2021 and the near future, efforts will be made to further develop small business and entrepreneurship in our country, to further increase the share of the private sector in the country's economy. It is noted that this sector will play a key role in the country's economy, occupying a leading position in the ongoing market reforms. However, there are a number of opportunities that are not used in small business and entrepreneurship, which are often related to the use of available local resources. Further improvement of operational efficiency can be achieved through the efficient use of available resources.

\section{MAIN PART}

Entrepreneurship is developing rapidly in developed economies. The share of entrepreneurs in their gross national product has risen to $70-80 \%$. More than $70 \%$ of the country's population is engaged in small business and private entrepreneurship.

Uzbekistan is also working hard to further develop entrepreneurship. Entities engaged in small business and entrepreneurship and their leaders strive to increase the amount of profit they receive along with the development of their activities. Entrepreneurs aim to make large profits while producing the products or services they need for the people of the country, province, city or district where they operate, creating new markets, and creating new jobs for the job-seeking population. . It will ultimately have an impact on improving the living conditions of the people in the country. Provides assistance to the needy part of the population. Entrepreneurs provide a large amount of sponsorship for the population in need of social assistance, distribute free medicines to patients, and the development of entrepreneurship benefits both themselves and those who work in their enterprises and organizations, as well as the population of the region where they are located. Therefore, the development of entrepreneurial activity was accepted as a key priority. For the further development of entrepreneurship, it is 
necessary, first of all, to study the theories of entrepreneurship and entrepreneurship from an economic point of view.

People have been engaged in entrepreneurship in our country since ancient times. Areas such as handicrafts and trade also existed before. However, their theoretical foundations have not been sufficiently established. Theoretical views on entrepreneurship, the rules, directions and principles for their development have not been sufficiently studied and adequately covered in the economic literature. After gaining independence, the focus began on entrepreneurial activity and its theoretical foundations. Entrepreneurship is now seen as a major driver of economic development, while at the same time playing an important role in providing employment, filling the market with the necessary consumer goods, developing the country's economy and improving the welfare of the population.

\section{RESULTS AND DISCUSSION}

Many scholars have tried to define small business and entrepreneurship. I.Shumpeter has done a lot of research on small business and entrepreneurship and as a result gives the following definition of entrepreneurship:

"Entrepreneurship is neither a career nor a profession, it is a unique ability to bring innovation to the market on a risk basis. Entrepreneur is not a capitalist, entrepreneurial activity is advanced, creative activity and is an important source of competitive reconstruction of the economy "(1). He connects entrepreneurship with innovative activity, believing that entrepreneurs will be at the level of creativity in creating innovation and bringing innovation to market. He believes that entrepreneurship is characterized by risk. Some business entities today do not pay attention to innovation at all, do not engage in innovative activities. As a result, it becomes difficult to achieve positive results in their activities.

Some time after I. Schumpeter, R., who had done much research in this direction. Hizrich believes that entrepreneurship is associated with creative activity and takes a risk. R. Hizrich described entrepreneurship as follows:

"Entrepreneurship is the process of creating something that has a certain value. An entrepreneur is a person who spends his time, knowledge and skills in the preparation and creation of something, he takes all the financial, mental and physical risks in this work, and as a result has a certain amount of money. "(2) Entrepreneurs are positive based on their risks. achieve results and gain efficiency. Many scholars have tried to define small business and entrepreneurship. I.Shumpeter has done a lot of research on small business and entrepreneurship and as a result gives the following definition of entrepreneurship:

"Entrepreneurship is neither a career nor a profession, it is a unique ability to bring innovation to the market on a risk basis. Entrepreneur is not a capitalist, entrepreneurial activity is advanced, creative activity and is an important source of competitive reconstruction of the economy "(1). He connects entrepreneurship with innovative activity, believing that entrepreneurs will be at the level of creativity in creating innovation and bringing innovation to market. He believes that entrepreneurship is characterized by risk. Some business entities 
today do not pay attention to innovation at all, do not engage in innovative activities. As a result, it becomes difficult to achieve positive results in their activities.

Some time after I. Schumpeter, R., who had done much research in this direction. Hizrich believes that entrepreneurship is associated with creative activity and takes a risk. R. Hizrich described entrepreneurship as follows:

"Entrepreneurship is the process of creating something that has a certain value. An entrepreneur is a person who spends his time, knowledge and skills in the preparation and creation of something, he takes all the financial, mental and physical risks in this work, and as a result has a certain amount of money. "(2) Entrepreneurs are positive based on their risks. achieve results and gain efficiency.

In recent years, especially after the independence of our country, our scientists and researchers began to study entrepreneurship and began to try to define entrepreneurship. One of the scientists of our country, namely Z.Ya. Khudoiberdiev tried to describe entrepreneurship:

"Entrepreneurship is a multidimensional socioeconomic situation, which is based on independent economic activity. It is for profit and arises from the combination of all material, financial and labor resources "(3). Z.Ya.Khudayberdiev considers entrepreneurial activity as an economically independent activity, and in this activity the integration of economic resources takes place, economic results are achieved.

The encyclopedic dictionary created in our country also defines entrepreneurship: "Entrepreneurship is an independent activity carried out on its own behalf, within the framework of its property liability or on behalf of a legal entity and with the purpose of obtaining profit or personal income on the basis of legal liability. An entrepreneur may carry out all types of economic activities not prohibited by law. They can be engaged in trade, brokerage, trade, purchase and sale, supply of products, agricultural activities, computer services, communication services and other similar activities "(4)

Summarizing the definitions and concepts of entrepreneurial activity, it can be described as follows:

Entrepreneurship is a special type of activity that leads to the saturation and satisfaction of market needs with products and services, despite the internal and external risks. Such activities benefit. Entrepreneurship and entrepreneurial activity means the independent activities of citizens aimed at making a profit within their own risks and property responsibilities. They invest their assets and capital in activities that are somewhat risky and risk-based, and seek to make a profit. The development of entrepreneurial activity has a high degree of influence on economic success and ensures high rates of production. Entrepreneurship is the basis of the innovative nature of the country's economy. Entrepreneurship accelerates the creation of innovations and their introduction into production. As their number and type of activity increases, the development of the economy progresses significantly. Through the development of entrepreneurial activity in the country, new, promising industries are developing. 
In recent years, as a result of the use of available resources by small businesses and entrepreneurs in our country, the following achievements have been made. In JanuaryMarch 2020, more than 23.3 thousand small enterprises and micro-firms were established. Most small businesses and micro-firms were established in the trade sector. $39.9 \%$ of the total number of established business entities in this area, $18.6 \%$ in industry, $11.3 \%$ in agriculture, forestry and fisheries, $7.9 \%$ in construction, $7.4 \%$ in accommodation and catering services, transportation and $2.8 \%$ in storage.

Based on the use of available resources, the following results were achieved by small businesses and entrepreneurs in the first quarter of 2020:
- The volume of industrial production amounted to 23630.8 billion. soums, which accounted for $28.7 \%$ of total industrial production;

- 18215.9 billion. UZS were invested. This is $54.6 \%$ of total investments and the growth rate compared to January-March 2019 was $126.8 \%$;

- $\quad 11172.4$ billion. soums worth of construction works were completed. Construction works accounted for $72.3 \%$ of the total. The growth rate compared to January-March 2019 was 107.1\%;

- $\quad 25823.7$ billion. soums were provided. This is $51.3 \%$ of the total volume of services in the country. The growth rate in this sector was 105.2\%;

Table 1

\section{Small business and private entrepreneurship}

Analysis of key indicators in the sectors of the economy in 2010-2020

\begin{tabular}{|c|c|c|c|c|c|}
\hline Years & $\begin{array}{c}\text { Industry } \\
\text { (billion } \\
\text { soums) }\end{array}$ & $\begin{array}{c}\text { Construction } \\
\text { (billion } \\
\text { soums) }\end{array}$ & $\begin{array}{c}\text { Employment } \\
\text { (thousand } \\
\text { people) }\end{array}$ & $\begin{array}{c}\text { Trade (billion } \\
\text { soums) }\end{array}$ & $\begin{array}{c}\text { Agriculture, } \\
\text { forestry and } \\
\text { fisheries } \\
\text { (billion soums) }\end{array}$ \\
\hline 2010 & 10132,9 & 4163,2 & 8643,9 & 18616,1 & 31900,4 \\
\hline 2011 & 13586,8 & 6188,3 & 8950,7 & 24741,9 & 46704,5 \\
\hline 2012 & 17114,6 & 7925,5 & 9239,7 & 32242,9 & 56926,6 \\
\hline 2013 & 23312,0 & 10377,7 & 9604,0 & 40564,5 & 67510,7 \\
\hline 2014 & 30907,0 & 13944,9 & 9950,8 & 50197,8 & 82957,2 \\
\hline 2015 & 39643,5 & 16954,0 & 10170,4 & 61972,3 & 101197,5 \\
\hline 2016 & 50654,5 & 19671,0 & 10397,5 & 78935,6 & 118011,4 \\
\hline 2017 & 61367,8 & 22469,4 & 10541,5 & 92973,0 & 152010,5 \\
\hline 2018 & 87962,0 & 37451,7 & 10128,8 & 114896,4 & 191759,2 \\
\hline 2019 & 83344,2 & 53960,9 & 10313,4 & 138920,7 & 219466,9 \\
\hline
\end{tabular}


The American Journal of Applied sciences

(ISSN - 2689-0992)

Published: April 29, 2021 | Pages: 111-118

\begin{tabular}{|c|c|c|c|c|c|}
\hline 2020 & 42274,4 & 30526,3 & 9402,0 & 75497,5 & 94634,4 \\
\hline $\begin{array}{c}\text { In 2020, } \\
\text { compared to } \\
2010, \% \text { In } \\
2020, \\
\begin{array}{c}\text { compared to } \\
2010 \%\end{array}\end{array}$ & 417,0 & 733,0 & 108,0 & 405,0 & 296,0 \\
\hline
\end{tabular}

In the first quarter of 2020, small business and entrepreneurial activity produced industrial products worth 42,274.4 billion soums (Table 1) and increased by $417.0 \%$ compared to 2010 . The construction sector achieved the highest growth during these years, with a change of $733.0 \%$. In all other areas, the growth rate of small business was also high. In the past, there have been some untapped opportunities in the export of goods and services. Along with the increase in exports, there has not been a sufficient increase in new modern types of exported products and services. At the same time, there have been some shortcomings in the field of efficient use of all economic resources in the country, and we will contribute to the development of small business and entrepreneurship through their elimination.

\section{CONCLUSIONS}

Based on the analysis and observations, we came to the following conclusions:

1. Comprehensive analysis of the economic potential of business enterprises.

2. In determining the goals and objectives of small business and entrepreneurship, take into account the conditions of globalization of the economy and set goals that are consistent with it.

3. Pay attention to the level of modernization of machine tools and equipment used in business enterprises. Look for modern and high-performance machines and look for financial opportunities to attract them.

4. Establish efficient use of all economic resources.

5. Take measures to increase the productivity of employees of the entrepreneurial enterprise, create the necessary conditions to achieve high productivity.

6. Further development of scientific organization of labor in entrepreneurship and small business.

At present, in order to identify problems in the development of small business and entrepreneurship, it is necessary to analyze their activities in the context of market relations. The market economy places great demands on the activities of business enterprises. The most important of such requirements is the conformity of manufactured products to market demand. This compliance must be ensured both quantitatively and qualitatively. The solution of these tasks depends in many respects on the economic potential of enterprises and the level of utilization of their opportunities. 


\section{REFERENCES}

1. Decree of the President of the Republic of Uzbekistan dated February 7, 2017 No. PF4947 "On the Action Strategy for further development of the Republic of Uzbekistan". Tashkent, “Uzbekistan", 2017.

2. Resolution of the President of the Republic of Uzbekistan dated June 7, 2018 No PP3777 "On the implementation of the Program" Every family is an entrepreneur. " National Database of Legislation, 08.06.2018, No. 07/08/377/1325.

3. Resolution of the President of the Republic of Uzbekistan dated March 7, 2019 No PP4231 "On additional measures for the broad involvement of the population in entrepreneurship and the development of family business in the regions."

4. Abdullaev Yo., Yuldashev Sh. Small business and entrepreneurship. - $\mathrm{T}$.: ECONOMY - FINANCE, 2008. 340 p.

5. Ristovska Katerina, Ristovska Aneta, Conference paper, "The impact of globalization on the business"

6. Olim Sabirovich Kazakov, \& Ilhom Mahamadjanovich Kamoliddinov. (2021). SOME QUESTIONS OF INCREASE OF EFFICIENCY IN ACTIVITY ENTERPRISE SUBJECTS. Journal of Central Asian Social Studies, 2(01), 160-169. https://doi.org/10.37547/jcass/volumeoziss ue01-a24

7. KazakovO. (2020). КИЧИК БИЗНЕС СУБЪЕКТИДА ИШЛАБ ЧИҚАРИШ ФАОЛИЯТИНИ РИВОЖЛАНТИРИШ ЙЎЛЛАРИ. Архив научных исследований, 1(2). извлечено от https://tsue.scienceweb.uz/index.php/arch ive/article/view/3729
8. Lutfulla Xabibullayevich Ubaydullayev, \& Bakhtiyor Nabijanovich Dedajanov. (2021). THE DIGITAL ECONOMY: ADVANTAGES AND RISKS. Journal of Central Asian Social Studies, 2(01), 153-159. https://doi.org/10.37547/jcass/volume02iss ue01-a23

9. Catter III, J.J., Kidwell, R.E. (2014). Function, governance, and trust in successor leadership groups in family firms. Journal of Family Business Strategy, 5(3), 217-228. doi: 10.1016/j.jfbs.2013.06.001.

10. Семейный бизнес или что такое хорошо и что такое плохо // Помощь бизнесу. http://bishelp.ru/

11. Chrisman, J. H., Chua, J. J., Sharma, P. (1998). Important Attributes of Successors in Family Businesses: An Exploratory Study. Family Business Review, 11(1), 19-34. doi: 10.1111/j.1741-6248.1998.00019.

12. Смит А. Исследование о природе и причинах богатства народов. - М.: Эксмо, 2016, - 1056 с.

13. Nabijanovich, D. B. (2019). Issues of support and stimulation of exporting enterprises and ways of their elimination. American Journal of Economics and Business Management, 2(3), 44-56.

14. Казаков О.С. Improving the management activity of the fruit and vegetable industry . Журнал “Theoretical \& Applied Science”№ 12/2018interprises.

15. Шумпетер.И. Теория экономического развития: исследования предпринимательской прибыли, капитала, кредита, процента и цикла коньюнктуры. Москва, Прогресс, 1982 год.

16. Хизрич. Р. , Питерс. М. Предпринимательство, или как завести собственное дело и добится успеха. Москва, Прогресс, 1990 йил. 
17. Казаков О.С. The Role of the Textile Industry in the Economy of Uzbekistan Журнал Asian Journal of Technology \& Management Research (AJTMR) ISSN: 2249-0892 Volg Issue-2, Dec -2019

18. KazakovO. (2020). КИЧИК БИЗНЕСНИНГ ЭКСПОРТ САЛОХИЯТИНИ ОШИРИШ. Архив научных исследований, 1(2). извлечено

OT https://tsue.scienceweb.uz/index.php/arch ive/article/view/3725

19. Катькало В.С., Панибратов А.Ю. Основы бизнеса: Учебник. -СПб.: Издат. дом С.Претерб. гос. ун-та, 2006. - 290 с.

20. Ғуломов С.С. Тадбиркорлик ва кичик бизнес. - Т.: “Шарқ” нашриёт-матбаа акциядорлик компанияси бош тахририяти. 2002. - 365 б.

21. Ўзбекистонда кичик тадбиркорлик. Статистик тўплам. Тошкент, 2020 й. 1906. 